\title{
Economic analysis of irrigated bean production in function of nitrogen fertilization management and inoculation of seeds
}

\section{Análise econômica da produção de feijão irrigado em função do manejo da adubação nitrogenada e inoculação de sementes}

\author{
Arthur PACHECO ${ }^{1}$; Adriano da Silva LOPES ${ }^{2}$; Omar Jorge SABBAG ${ }^{3}$; Eder Duarte FANAYA JÚNIOR ${ }^{4}$ \\ Marcos Jefferson KRAESKI ${ }^{5}$; Fernando Braz Tangerino HERNANDEZ ${ }^{6}$; \\ Carla Deisiane de Oliveira Costa do VAL ${ }^{7}$; Adriano de FRANÇA ${ }^{8}$
}

\begin{abstract}
${ }^{1}$ Doutor pela Universidade Estadual de Mato Grosso do Sul, Programa de Pós-graduação em Agronomia, Área de concentração: Produção Vegetal, Grupo de Estudo e Pesquisa em Irrigação - GEPI. arthur_ap@hotmail.com

2 Professor Associado da Universidade Estadual de Mato Grosso do Sul, Programa de Pós-graduação em Agronomia, Área de concentração: Produção Vegetal. Grupo de Estudo e Pesquisa em Irrigação - GEPI. lopes@uems.br

${ }^{3}$ Pós-Doutor e Livre-Docente do Departamento de Fitotecnia, Tecnologia de Alimentos e Sócioeconomia (DFTASE), UNESP - campus de Ilha Solteira, Área: Economia e Gestão do Agronegócio. omar.sabbag@unesp.br

${ }^{4}$ Autor para correspondência. Pós-Doutorando na Universidade Estadual de Mato Grosso do Sul, Programa de Pósgraduação em Agronomia, Área de concentração: Produção Vegetal, Grupo de Estudo e Pesquisa em Irrigação - GEPI. Rodovia Graziela Maciel Barroso, km 12, Zona Rural, Aquidauana-MS. eder.fanayaj@@alumni.usp.br

${ }^{5}$ Doutorando na Universidade Estadual de Mato Grosso do Sul, Programa de Pós-graduação em Agronomia, Área de concentração: Produção Vegetal, Grupo de Estudo e Pesquisa em Irrigação - GEPI. marcos_kraeski@hotmail.com

${ }^{6}$ Professor Titular no Departamento de Fitossanidade, Engenharia Rural e Solos - DEFERS, Faculdade de Engenharia, UNESP - campus de Ilha Solteira, Área: Irrigação e Drenagem. fernando.braz@unesp.br

7 Pós-Doutora na Universidade Estadual de Mato Grosso do Sul, Programa de Pós-graduação em Agronomia, Área de concentração: Produção Vegetal, Laboratório de Irrigação. carladeisiane@hotmail.com

${ }^{8}$ Mestrando na Universidade Estadual de Mato Grosso do Sul, Programa de Pós-graduação em Agronomia, Área de concentração: Produção Vegetal. adrianogll@hotmail.com
\end{abstract}

Recebido em: 03-04-2020; Aceito em: 02-06-2020

\begin{abstract}
The best period and method for the application of nitrogen fertilization, as well as the use of inoculation or not of bean seeds, are variables that can be of great value to the producer from an agroeconomic point of view when considering the selection of the correct irrigation management. So, the aim of this study was to perform an economic analysis of the irrigated bean, according to different fertilization managements and seed inoculation. The work was conducted in the municipality of Aquidauana-MS, Brazil in the experimental area of the State University of Mato Grosso do Sul, using the cultivar IAC Milênio with sowing during the winter season. The experimental was setup in a completely randomized block design with four replications. Nitrogen fertilization (sowing, cover and foliar) and seed inoculation (absence and presence) were used in the plots. For economic analysis of the irrigated common bean, calculation of the total production cost was performed, in function of the effective operational cost and the total operational cost. To determine the profitability of the treatments involved, the following values were calculated: gross revenue, net revenue, profitability index, equilibrium price and equilibrium productivity. The economic analysis response of the irrigated bean varied according to the different fertilization managements and inoculation of seeds, where nitrogen application at sowing and seed inoculation presented economic results. Although the cost of production varied little, the profitability indices of each treatment vary in function of the productivity obtained. Nitrogen fertilization at sowing and inoculation of seeds with Rhizobium tropici provided increased net revenue for the common bean.
\end{abstract}

Additional keywords: effective operational cost, nitrogen fertilization, Phaseolus vulgaris L., profitability of common bean, Rhizobium tropici, total operational cost.

\section{Resumo}

O melhor período e método para a aplicação da adubação nitrogenada, bem como o uso da inoculação ou não das sementes de feijão, são variáveis que podem ser de grande valor para o produtor do ponto de vista agroeconômico ao considerar a seleção do manejo correto da irrigação. O objetivo desse trabalho foi realizar a análise econômica do feijoeiro irrigado, de acordo com diferentes manejos de adubação e inoculação de sementes. $O$ trabalho foi conduzido no município de Aquidauana - MS, utilizando a cultivar IAC Milênio com semeadura na época de inverno. O delineamento experimental utilizado foi em blocos casualizados contendo quatro blocos, sendo empregados nas parcelas a adubação nitrogenada (semeadura, em cobertura e foliar) e inoculação de sementes (ausência e presença). Para a análise econômica do feijoeiro irrigado foi realizado o cálculo do custo total de produção, em função da soma do custo operacional efetivo e do custo operacional total. Para determinar a 
rentabilidade dos tratamentos envolvidos, foram calculados os seguintes itens: receita bruta, receita líquida, índice de lucratividade, preço de equilíbrio e a produtividade de equilíbrio. A análise econômica do feijoeiro irrigado variou de acordo com os diferentes manejos de adubação e inoculação de sementes, tendo a semeadura com nitrogênio e a inoculação de sementes apresentado os resultados econômicos. Apesar do custo total de produção ter apresentado pouca variação, os índices de lucratividade de cada tratamento variaram em função da produtividade obtida. A adubação de semeadura com nitrogênio e inoculação de sementes com Rhizobium tropici propiciou aumento receita líquida para o feijoeiro.

Palavras-chave adicionais: adubação nitrogenada, custo operacional efetivo, custo operacional total, Phaseolus vulgaris L., rentabilidade do feijoeiro, Rhizobium tropici.

\section{Introduction}

The common bean (Phaseolus vulgaris, L.) is a important crop in nutritional food security and traditional cooking of different countries. It's one of the main crops produced in Brazil and for this reason it plays a very important economic role (Barbosa \& Gonzaga, 2012).

Considering its importance at the national level, knowledge of fertilization practices adopted by producers is needed, which together with other cultural practices such as irrigation and phytosanitary treatments, contribute to increased production (Gerlach et al., 2013).

According to Pegoraro et al. (2014), Nitrogen $(\mathrm{N})$ is one of the nutrients most absorbed by the bean, and the maximum accumulation rate in the leaves and stem is between 26 and 36 days after emergence - DAE (R5-R6); in the reproductive organs pods and grains this maximum rate is observed between 46 and 66 DAE (stages R7-R8).

Even so, fertilization has a significant impact on the composition of bean production costs. In this context, considering the cost of $\mathrm{N}$ fertilizers, it's fundamental importance to develop adequate management techniques that seek the best use of $\mathrm{N}$ by the crop and the best economic situation (Esperancini et al., 2015).

In addition to $\mathrm{N}$ fertilization, the correct irrigation management of the winter bean may be an alternative to aid root growth of the crop and absorption of nutrients from the soil. Thus Alves Júnior et al. (2018) reported that implantation of a central pivot irrigation system is feasible for the soybean, corn and tomato cultivation, under the edaphoclimatic conditions of the Cerrado in the Brazilian state of Goiás.

Another alternative to reduce nitrogen fertilizer costs may be the use of bacteria from the genus Rhizobium, which under environmental conditions are able to at least partially supply the nitrogen demand of the plant. However, efficiency of this microorganism is highly variable and may not be sufficient to fully meet the entire $N$ demand, especially when seeking high productivity (CTSBF, 2012).

Studies contributing to a more efficient indication of the best period and method for application of the nitrogen fertilization, as well as inoculation or not of the bean seeds, are of great value to the producer from an agroeconomic point of view when considering selection of the correct irrigation management (Gerlach et al., 2013).

The use of seed inoculation by Rhizobium tropici, can reduce the costs arising from nitrogen fertilizer applications, maintaining the productivity of irrigated beans. In this context, the aim of the present study was to conduct an economic analysis of the irrigated bean in Aquidauana - MS, Brazil, according to different fertilization management techniques and seed inoculation.

\section{Material and methods}

This study was carried out in the municipality of Aquidauana - MS, Brazil $\left(20^{\circ} 27^{\prime} 08^{\prime \prime} \mathrm{S}, 55^{\circ} 40^{\prime} 15^{\prime \prime} \mathrm{W}\right.$ and local elevation of $191 \mathrm{~m}$ ), in soil identified as Dystrophic Red Argosol (Schiavo et al., 2010). According to the Köppen classification the regional climate is described as Aw, defined as a subhumid tropical climate with a rainy season in the summer and dry season in the winter (Alvares et al., 2014), and average annual rainfall ${ }^{1}$ of $1282.7 \mathrm{~mm}$.

The experiment was setup in a randomized complete block design, and the fertilization and inoculation treatments used in the plots, described below:

- $\quad \mathrm{T} 1$ - only with Nitrogen (N) applied at sowing;

- T2 - with $\mathrm{N}$ applied at sowing and topdress $\mathrm{N}$ in vegetative stage V4 (opening of the third leaf trifoliate and formation of branches in the buds of the lower nodes);

- T3 - with $\mathrm{N}$ applied at sowing and foliar $\mathrm{N}$ applied at the vegetative stage R5 (appearance of the first floral bud and the first raceme);

- T4 - with $\mathrm{N}$ applied at sowing and seeds inoculation with Rhizobium tropici Semia 4077;

- T5 - with $\mathrm{N}$ applied at sowing, seeds inoculation with Rhizobium tropici Semia 4077 and topdress $\mathrm{N}$ in vegetative stage $\mathrm{V} 4$;

- T6 - with seeds inoculation by Rhizobium tropici Semia 4077 and topdress $N$ in vegetative stage V4;

- T7 - with $\mathrm{N}$ applied at sowing and Molybdenum (Mo) leafing applied at the vegetative stage V4; 
Each experimental plot consisted of 4 plant rows measuring $6 \mathrm{~m}$ in length, where the useful area of each plot consisted of the two central lines along $5 \mathrm{~m}$, totaling $4.5 \mathrm{~m}^{2}$.

Before initiating the experiment, a chemical analysis of the soil was conducted (Table 1), a basis for potassium and phosphate fertilization according to the recommendations of Barbosa \& Gonzaga (2012). Single superphosphate $\left(70 \mathrm{~kg}\right.$ of $\left.\mathrm{P}_{2} \mathrm{O}_{5} \mathrm{ha}^{-1}\right)$ was used as a source of phosphate and potassium chloride $\left(70 \mathrm{~kg}\right.$ of $\left.\mathrm{K}_{2} \mathrm{O} \mathrm{ha}^{-1}\right)$ as a source of potassium.
$\mathrm{N}$ fertilization was performed according to the treatments, in which urea was used as a $\mathrm{N}$ source at the rate of $40 \mathrm{~kg} \mathrm{ha}^{-1}$ of $\mathrm{N}$, being applied exclusively at sowing or in the case of topdress application divided among the different development stages.

The seeds were treated with carboxy + thiram fungicide $\left(45.2+45.2 \mathrm{~g}\right.$ of a.i. ha $\left.^{-1}\right)$ and sowing was performed mechanically in a conventional soil management system on June 30, 2016 using the cultivar IAC Milênio, with row spacing of 0.45 and 16 seeds per meter.

Table 1 - Soil chemical analysis at the depth of 0.0 to $0.2 \mathrm{~m}$.

\begin{tabular}{|c|c|c|c|c|c|c|c|c|c|c|c|}
\hline $\mathrm{pH}^{*}$ & $\begin{array}{c}\mathrm{P} \\
\left(\mathrm{mg} \mathrm{dm}^{-3}\right)\end{array}$ & $\begin{array}{l}\text { O.M. } \\
(\%)\end{array}$ & Texture & $\mathrm{K}$ & $\mathrm{Ca}$ & $\mathrm{Mg}$ & $\begin{array}{c}\mathrm{Al} \\
\left(\mathrm{cmol}_{\mathrm{c}} \mathrm{dm}\right.\end{array}$ & $\begin{array}{c}\mathrm{H}+\mathrm{Al} \\
\left.7^{-3}\right)\end{array}$ & SB & $\mathrm{T}$ & $\begin{array}{c}\mathrm{V} \\
(\%)\end{array}$ \\
\hline 5.7 & 55.8 & 2.5 & ** & 0.16 & 3.75 & 1.00 & 0.00 & 2.97 & 4.91 & 7.88 & 62.3 \\
\hline
\end{tabular}

${ }^{*} \mathrm{pH}$ in water 1:2.5; O.M. (Organic Material); ${ }^{* *}$ Clay concentration less than $15 \%$; SB (Sum of bases); T (CEC at pH 7.0); $\mathrm{V}$ (Cation bases saturation).

The study was performed during the winter growing season under a central pivot irrigation system, where irrigation management was performed using the Penman-Monteith equation based on the estimation of reference evapotranspiration (ETo) according to Allen et al. (1998), with a soil water depletion factor "p" of 0.5. With the ETo value, crop evapotranspiration (ETc) was estimated according to Equation 1.

$\mathrm{ETc}=\mathrm{ETO} \times \mathrm{Kc}$

Wherein: $\mathrm{ETC}=$ Crop evapotranspiration $\left(\mathrm{mm}\right.$ day $\left.^{-1}\right)$; $\mathrm{ETo}=$ Reference evapotranspiration $\left(\mathrm{mm}\right.$ day $\left.^{-1}\right) ; \quad \mathrm{Kc}$ $=$ Crop coefficient (dimensionless), which used values of 0.25 for the initial phase and vegetative development; 1.15 for stage of flowering and filling of grains; and 0.35 for the maturation phase (Allen et al., 1998).

The data used in the Penman-Monteith equation were collected from the UEMS weather station, located near the study area. For the treatments that received seed inoculation, the Rhizobium tropici Semia 4077 strain was used at the dose of $134 \mathrm{~g}$ of the turfous inoculant per hectare $(80 \mathrm{~g}$ of inoculant for 50 $\mathrm{kg}$ of seeds). Weed management was done postemergence with a single application of the herbicide fluazifop-p-butyl ( $187.5 \mathrm{~g}$ of a.i. ha $\left.{ }^{-1}\right)+$ fomesafen (250 $\mathrm{g}$ of a.i. ha-1). Disease control was carried out with three applications of the fungicide trifloxystrobin $(75 \mathrm{~g}$ of a.i. ha $\left.{ }^{-1}\right)+$ tebuconazole $\left(150 \mathrm{~g}\right.$ of a.i. ha $\left.{ }^{-1}\right)$. Pest control was performed in two moments using the insecticide beta-cyfluthrin ( $5 \mathrm{~g}$ of a.i. ha ${ }^{-1}$ ).

The mechanized operations were performed with a $110 \mathrm{hp}$ tractor, using an intermediate harrow (18 discs of 28"), leveling disc (44 discs of 20"), 9 row fertilizer planter with row spacing of $0.45 \mathrm{~m}$, topdress fertilizer with $10 \mathrm{~m}$ range and $12 \mathrm{~m}$ bar sprayer. Harvest was performed 91 days after emergence in two operations, the first using a reaper/rake and the second with the aid of a collector/thresher.

The cost of production was calculated using the model of the Institute of Agricultural Economics (IEA), where the effective operating cost (EOC) was comprised of those related to mechanized (depreciation and machine-hour) and/or manual operations (manhour), inputs (bags, tons and doses) and electricity (kWh). The total operational cost (TOC) was composed of the EOC plus expenses of $9.5 \%$ p.a. (MAPA, 2016) over $50 \%$ of the EOC and additional operating expenses ( $5 \%$ of the EOC). Finally, by adding the TOC to the land compensation factor, the total production cost (TPC) was obtained (Matsunaga et al., 1976).

Assessment of the technical coefficients of the experiment was based on the information of experienced technicians in the region and the respective prices were quoted in Brazilian Real currency $(R \$)$ and the US dollar (US\$), fixed according to the Central Bank of Brazil at the time of determining the technical coefficients as $\mathrm{R} \$ 3.32$ per US dollar (BCB, 2018). Each treatment was considered as a commercial crop and the treatments of fertilization and inoculation were used as variations.

The production cost worksheets were elaborated by multiplying the technical coefficients of production by the factor prices, per unit area (hectare). Regarding linear depreciation, the values were duly calculated in relation to the useful life of each fixed capital asset.

To determine profitability of the treatments involved, the following items were calculated: gross revenue (GR), net revenue (NR), profitability index (PI), equilibrium price (EP) and equilibrium productivity (EPro) (Martin et al., 1998).

\section{Wherein:}

a) GR (in $\mathrm{R} \$$ ) is the product between the quantity produced (in number of $60 \mathrm{~kg}$ bags) and the average price received by the producer (in $\mathrm{R} \$$ ) (Equation 2):

$\mathrm{GR}=$ quantity produced $\times$ unit price 
b) NR (in $\mathrm{R} \$$ ) is the difference between the gross revenue and total cost of production (Equation 3):

$\mathrm{NR}=\mathrm{GR}-\mathrm{TPC}$

c) $\mathrm{PI}(\%)$, understood as the ratio of gross revenue that is made up of available resources, after covering the total operational cost of production (Equation 4):

$\mathrm{PI}=(\mathrm{NR} / \mathrm{GR}) \times 100$

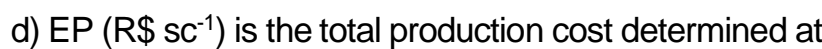
a given level as the minimum price necessary to meet the TPC, considering the average productivity obtained by the producer (Equation 5):

$E P=T P C /$ average productivity obtained by the producer

e) EPro $\left(\mathrm{sc} \mathrm{ha}^{-1}\right)$ is the total production cost determined at a given level as the minimum productivity necessary to meet the TPC, considering the average price received by the producer (Equation 6):

$\mathrm{EPro}=\mathrm{TPC} /$ average price received by the producer
The bean market can be very volatile, depending on the internal availability of the product. The average price of a bean sac was therefore $R \$ 169.63$, and was calculated by means of average values of the three winter crops in September, equal to $R \$ 54.93$ (2013/2014 harvest), $R \$ 98.97$ (2014/2015 harvest) and $\mathrm{R} \$ 355.00$ (2015/2016 harvest) (CONAB, 2018).

In accordance with the traditional method of commercializing grains in the region, the productivity values of the treatments were converted into $60 \mathrm{~kg}$ sacs (sc) of the grain.

\section{Results and discussion}

The total production cost (TPC) model was made individually for all treatments. For a better interpretation of the cost data, the Table 2 represents the Penman-Monteith irrigation management, in which the seeds inoculation by Rhizobium tropici and topdress fertilization in vegetative stage 4 (Treatment 6 for fertilization) was carried out.

Table 2 - Estimate of the operational cost per hectare obtained for the irrigated bean crop in function of seed inoculation with Rhizobium tropici and topdress fertilization with urea in vegetative stage 4 (T6) in the municipality of Aquidauana-MS, Brazil, during the 2015/2016 crop season.

\begin{tabular}{|c|c|c|c|c|c|}
\hline \multirow{2}{*}{ Description } & \multirow{2}{*}{ Specification } & \multirow{2}{*}{ No. of times } & \multirow{2}{*}{ Quantity } & Unit value & Total \\
\hline & & & & \multicolumn{2}{|c|}{-------- $(\mathrm{R} \$)$--------- } \\
\hline $\begin{array}{l}\text { Mechanized operations } \\
\text { Spraving }\end{array}$ & $\mathrm{MH}$ & 6 & & & \\
\hline Harrowing & $\mathrm{MH}$ & $\begin{array}{l}0 \\
2\end{array}$ & 0.71 & $\begin{array}{r}3.40 \\
33.00\end{array}$ & $\begin{array}{r}2.65 \\
46.86\end{array}$ \\
\hline Disc leveler & $\mathrm{MH}$ & 1 & 0.48 & 17.30 & 8.30 \\
\hline Topdress fertilization & $\mathrm{MH}$ & 1 & 0.10 & 3.30 & 0.33 \\
\hline Sowing & $\mathrm{MH}$ & 1 & 0.53 & 24.30 & 12.88 \\
\hline Harvest (reaper and rake) & $\mathrm{MH}$ & 1 & 0.40 & 13.20 & 5.28 \\
\hline Harvest (harvester and & $\mathrm{MH}$ & 1 & 0.71 & 33.00 & 23.43 \\
\hline Irrigation & $\mathrm{mm}$ & 10 & 189.00 & 0.52 & 97.37 \\
\hline Labor & $\mathrm{R} \$$ & - & - & - & 90.00 \\
\hline \multicolumn{5}{|l|}{ Inputs } & 287.11 \\
\hline Fluazifop-P-Butyl Herbicide & L & 1 & 0.75 & 105.00 & 78.75 \\
\hline Herbicide fomesafen & $\mathrm{L}$ & 1 & 1.00 & 105.00 & 105.00 \\
\hline Carboxy + thiram fungicide & L & 1 & 0.23 & 29.00 & 6.55 \\
\hline Trifloxystrobin + & $\mathrm{L}$ & 3 & 0.75 & 145.00 & 326.25 \\
\hline Insecticide (Beta- cyfluthrin) & $\mathrm{L}$ & 2 & 0.10 & 250.00 & 50.00 \\
\hline Seeds (IAC Milênio) & $\mathrm{kg}$ & 1 & 103.00 & 7.00 & 721.00 \\
\hline Simple superphosphate & $\mathrm{t}$ & 1 & 0.39 & 1400.00 & 543.20 \\
\hline Potassium chloride & $\mathrm{t}$ & 1 & 0.17 & 1600.00 & 265.60 \\
\hline Urea & $t$ & 1 & 0.09 & 1700.00 & 149.60 \\
\hline Inoculant (Rhizobium tropici) & $\mathrm{kg}$ & 1 & 0.13 & 143.00 & 19.16 \\
\hline \multicolumn{4}{|l|}{ Subtotal B } & & $2,265.12$ \\
\hline \multicolumn{4}{|l|}{ Effective operating cost (EOC) } & & $2,552.22$ \\
\hline \multicolumn{4}{|l|}{ Other expenses } & & 127.61 \\
\hline \multicolumn{4}{|c|}{ Depreciation of machinery and equipment * } & & 267.79 \\
\hline \multicolumn{4}{|l|}{ Interest costs } & & 121.23 \\
\hline \multicolumn{4}{|l|}{ Total operating costs (ROC) } & & $3,068.85$ \\
\hline \multicolumn{4}{|l|}{ Land compensation* ${ }^{*}$} & & 240.00 \\
\hline \multicolumn{4}{|l|}{ Total Production Cost (TPC) } & & $3,308.86$ \\
\hline
\end{tabular}

Source: Research data. ${ }^{*}$ Data referring to the proportional cost based on 2.5 harvest per year. $\mathrm{MH}-$ Machine-hour. 
It was found that the effective operating cost (EOC) for treatment 6 was $R \$ 2,552.22$ (Table 2). Of this amount, costs with fertilizers, seeds and pesticides were the highest, corresponding to $37.5 \%, 28.3 \%$ and $22.2 \%$ of the EOC, respectively. Lopes et al. (2011) verified that the main components of the EOC ( $R \$ 2,223.78)$ were fertilizer $(21.4 \%)$, seeds $(17.5 \%)$ and pesticides $(6.6 \%)$.

The percent increases in relation to the work of Lopes et al. (2011) can be justified as a result of the increased costs of the products used, and according to data from the Central Bank of Brazil the exchange rate in 2010 and 2011 ranged from $R \$ 1.55$ to $R \$ 1.90$ per dollar, while in the present study the exchange rate was $\mathrm{R} \$ 3.32$ (BCB, 2018).

The input cost was $88.7 \%$ and mechanized operations accounted for $11.3 \%$ of the EOC. In a study conducted by Gerlach et al. (2013) in Selvíria-MS,
Brazil, on irrigated beans, the costs related to inputs and mechanized operations were $57.2 \%$ and $26.7 \%$ of the EOC, respectively, also considering values with manual harvest operations (16.1\%).

High input costs were in alignment with the work of Gerlach et al. (2013), where these results are mainly due to the cost of seeds and fertilizers. In the present study, the costs of seeds and fertilizers were $\mathrm{R} \$$ 721.00 and $R \$ 958.00$, respectively. In the study conducted by Gerlach et al. (2013) the costs were $\mathrm{R} \$$ 270.00 and $R \$ 225.00$, indicating cost increases of more than $250 \%$ for seeds and more than $400 \%$ for fertilizer.

The observed TPC values ranged from $R \$ 3,287.46$ ( $T 1$ ) to $R \$ 3,308.86$ ( $T 5$ and $T 6$ ). This difference is due to the fact that $\mathrm{T} 5$ and $\mathrm{T} 6$ received inoculation of seeds with Rhizobium tropici (Table 3).

Table 3 - Profitability of the irrigated bean crop, with fertilization and inoculation of seeds in the municipality of Aquidauana-MS, Brazil, 2015/2016 harvest.

\begin{tabular}{lcccrrrr}
\hline Treatment & $\begin{array}{c}\text { GP } \\
\left(\mathrm{sc} \mathrm{ha}^{-1}\right)\end{array}$ & \multicolumn{1}{c}{ TPC } & $\begin{array}{c}\text { GR } \\
--------------(\mathrm{R} \$)\end{array}$ & $\mathrm{NR}$ & $\begin{array}{c}\text { PI } \\
(\%)\end{array}$ & $\begin{array}{c}\text { EPro } \\
\left(\mathrm{sc} \mathrm{ha}^{-1}\right)\end{array}$ & $\begin{array}{c}\text { EP } \\
\left(\mathrm{R} \$ \mathrm{sc}^{-1}\right)\end{array}$ \\
\hline T1 & 43.6 & $3,287.46$ & $7,401.67$ & $4,114.20$ & 55.58 & 19.38 & 75.34 \\
T2 & 16.0 & $3,287.83$ & $2,714.13$ & -573.69 & -21.14 & 19.38 & 205.49 \\
T3 & 28.3 & $3,287.95$ & $4,800.62$ & $1,512.67$ & 31.51 & 19.38 & 116.18 \\
T4 & 46.1 & $3,308.49$ & $7,814.44$ & $4,505.95$ & 57.66 & 19.50 & 71.82 \\
T5 & 43.6 & $3,308.86$ & $7,401.67$ & $4,092.81$ & 55.30 & 19.51 & 75.83 \\
T6 & 42.7 & $3,308.86$ & $7,246.17$ & $3,937.31$ & 54.34 & 19.51 & 77.46 \\
T7 & 37.7 & $3,287.95$ & $6,400.83$ & $3,112.88$ & 48.63 & 19.38 & 87.14 \\
\hline
\end{tabular}

Source: research data. GP - Grain productivity; TPC - Total production cost; GR - Gross revenue; NR - Net revenue; PI - Profitability index; EPro - Equilibrium productivity; EP - Equilibrium price; T1 - Fertilization at sowing with N; T2 - Fertilization at sowing with $\mathrm{N}$ and topdress fertilization in stage V4; T3 - Fertilization at sowing with $\mathrm{N}$ and leaf fertilization in stage R5; T4 - Fertilization at sowing with $\mathrm{N}$ and seed inoculation; T5 - Fertilization at sowing with $\mathrm{N}$, topdress fertilization in stage $\mathrm{V} 4$ and seed inoculation; T6 - Topdress fertilization in stage V4 and seed inoculation; T7 - Fertilization at sowing with N and leaf molybdenum (Mo) application in stage $\mathrm{V} 4$.

In general, the average total production cost for the irrigated bean in Aquidauana-MS, Brazil was $R \$ 3,296.77$ in the 2015/2016 crop year with average productivity among the studied treatments of $36.9 \mathrm{sc} \mathrm{ha}^{-1}$.

According to the Federation of Agriculture and Livestock of Goiás, the TPC of the irrigated bean in November 2016 was $R \$ 4,479.53$, and $R \$ 4,056.53$ for the regime without irrigation, with average expected yields of $50 \mathrm{sc} \mathrm{ha}^{-1}$ and $40 \mathrm{sc} \mathrm{ha}^{-1}$, respectively. This indicates that the TPC in the irrigated crop was 9.5\% higher than $25 \%$ yield was obtained in relation to the crop without irrigation. Thus, the higher cost of the irrigated crop was offset by higher productivity (FAEG, 2018).

The highest GP (46.1 sc ha-1) was observed in the treatment which included nitrogen fertilization and seed inoculation (T4), and the lowest was observed in T2 (nitrogen fertilization at sowing and nitrogen fertilization in the V4 stage). Consequently, the highest and lowest gross revenue (GR) values were observed for these treatments (T4 and T2), respectively, where the GR for T4 was $R \$ 7,814.44$ and for $T 2$ was $R \$$ $2,714.13$. These results indicate that the GR in T4 was about $188 \%$ greater than that of T2.

Also, in Table 3 are the values referring to net revenue (NR) and the profitability index (PI), T4 showed the highest NR and $\mathrm{PI}$ values $(\mathrm{R} \$ 4,505.95$ and $57.66 \%$, respectively). However, treatments T1, T5 and T6 also obtained PI above $50 \%$. Treatment T2 presented a negative NR of $R \$ 573.69$ and was the only treatment in which the PI was negative at $21.14 \%$.

The equilibrium productivity (EPro) and the market values of the $60 \mathrm{~kg}$ bean sac with regards to the equilibrium price $(\mathrm{PE})$ are shown in Table 3 . It is possible to verify that for the $60 \mathrm{~kg}$ bean sac price ( $R \$ 169.63)$, the treatments obtained average equilibrium productivity values of $19.43 \mathrm{sc} \mathrm{ha}^{-1}$.

According to the assessment carried out by the Companhia Nacional de Abastecimento, the average grain yield of the bean in color for the third crop of 2015/2016 was $17.23 \mathrm{sc} \mathrm{ha}^{-1}$ (CONAB, 2017). In this case the minimum productivity of the Brazilian crop would not be sufficient to cover the total production costs of the present study. 
In relation to the EP (minimum sac price to cover the costs according to the productivity obtained), prices ranged from $R \$ 71.82$ to $R \$ 205.49$, represented by T4 and T2, respectively. Treatment T2 presented EP greater than the actual price of the sac by about $21 \%$, i.e., the productivity for this treatment was not sufficient to cover the TC based on the sac value $(R \$ 169.63)$.

In general, the treatment with nitrogen fertilization and seed inoculation was that which allowed the lowest equilibrium price, i.e., the lowest price necessary to cover the costs.

\section{Conclusions}

Profitability of the irrigated common bean varies according to the different fertilization management techniques and inoculation of seeds, with nitrogen fertilization and seed inoculation presenting economic results.

Although the total production cost varies little, the profitability indices of each treatment vary according to the productivity obtained.

Nitrogen fertilization at sowing and seeds inoculation with Rhizobium tropici resulted in higher revenue values for bean production.

\section{References}

Allen RG, Pereira LS, Raes D, Smith M (1998) Crop evapotranspiration: guidelines for computing crop requirements. FAO. 300p.

Alvares CA, Stape JL, Sentelhas PS, Gonçalves JLM, Sparovek G (2014) Köppen's climate classification map for Brazil. Meteorologische Zeitschrift. 22 (6): 711--728.

Alves Júnior J, Sales DLA, Pereira RM, Rodriguez WDM, Casaroli D, Evangelista AWP (2018) Viabilidade econômica da irrigação por pivô central nas culturas de soja, milho e tomate. Pesquisa Agropecuária Pernambucana. 22 (201703): 1-6. doi: 10.12661/pap.2017.011

Barbosa FR, Gonzaga ACO (2012) Informações técnicas para o cultivo do feijoeiro-comum na Região Central-Brasileira: 2012-2014. Embrapa Arroz e Feijão. $247 p$.

BCB - Banco Central do Brasil. (2018) Cotações e boletins. Disponível em: $<$ http://bcb.gov.br/pec/taxas/port/ptaxnpesq.asp?id=txc otacao> (Acesso em 22 nov 2018).

CTSBF - Comissão Técnica Sul-Brasileira de Feijão (2012) Informações técnicas para o cultivo de feijão na Região Sul brasileira. 157p.

CONAB - Companhia Nacional de Abastecimento. (2018) Preços médios mensais para o Estado de Mato Grosso do Sul 2018. Disponível em: <http://sisdep.conab.gov.br/precosiagroweb/> (Acesso em 28 mar 2018).
CONAB - Companhia Nacional de Abastecimento. (2017) Acompanhamento da safra brasileira. Grãos Safra 2016/2017, Oitavo levantamento, 4 (8): 130p.

Esperancini MST, Afonso PFN, Gava GJC, Boas RLV (2015) Dose ótima econômica de nitrogênio em cana- de-açúcar aplicada via fertirrigação por gotejamento. Irriga. 1 (1, Ed. Especial, 20 anos Irriga + 50 anos FCA): 28-39. doi: 10.15809/irriga.2015v1n1p28.

FAEG - Federação da Agricultura e Pecuária de Goiás. (2018) Estimativa de Custo de Produção. Disponível em: <http://sistemafaeg.com.br/mercados-ecotacoes/custo-de-producao> (Acesso em 07 mai 2018).

Gerlach GAX, Arf O, Corsini DC, Silva JC, Coletti AJ (2013) Análise econômica da produção de feijão em função de doses de nitrogênio e coberturas vegetais. Pesquisa Agropecuária Tropical. 43 (1): 42-49.

Lopes AS, Pavani LC, Tarsitano MAA, Proença ER (2011) Avaliação econômica da cultura do feijoeiro de inverno em Jaboticabal - SP. Científica. 39 (1/2): 18-24.

MAPA - Ministério da Agricultura, Pecuária e Abastecimento (2016) Preços médios mensais. Secretaria de Política Agrícola. 46p.

Martin NB, Serra R, Oliveira MDM, Ângelo JÁ, Okawa H (1998) Sistema "CUSTAGRI": sistema integrado de custo agropecuário. Informações Econômicas. 28 (1): 4-7.

Matsunaga M, Bemelmans PF, Toledo PEN, Dulley RD, Okawa H, Pedroso IA (1976) Metodologia de custo de produção utilizada pelo IEA. Agricultura em São Paulo (Brasil). Instituto de economia agrícola. 23 (1):123-139.

Pegoraro RF, Oliveira D, Moreira CG, Kondo MK, Portugal AF (2014) Partição de biomassa e absorção de nutrientes pelo feijoeiro comum. Revista Caatinga. 27 (3): 41-52.

Schiavo JA, Pereira MG, Miranda LPM, Dias Neto AH, Fontana A (2010) Caracterização e classificação de solos desenvolvidos de arenitos da formação Aquidauana-MS. Revista Brasileira de Ciência do Solo. 34 (3): 881-889. doi: 10.1590/S010006832010000300029. 